\title{
Effect of Green Shade Net on Yield and Quality of Tomato
}

\author{
Deepak Chouhan*, Mrigendra Singh, P.N. Tripathi and Alpana Sharma \\ Krishi Vigyan Kendra, Shahdol, J.N.K.V.V. Jabalpur, India \\ *Corresponding author
}

\begin{abstract}
A B S T R A C T
\end{abstract}
\section{Keywords \\ Shade net, Tomato, Yield, Plant characteristics \\ Article Info \\ Accepted: \\ 16 August 2018 \\ Available Online: \\ 10 September 2018}

\begin{abstract}
The performance of green shade net on yield and quality of tomato was evaluated at farmers field in Shahdol district. Under shade net house condition green colour shade net having $50 \%$ shade factor was used in the study. Similar crop along with similar cultural practices in the open field and shade net cultivation was selected for performance evaluation. The study revealed that under shade net condition performance of tomato the crop yield, number of fruit per plant, fruit weight, plant height, harvest duration and number of harvest increased by 75.32 per cent, 61 per cent, 76.3 per cent, 40.03 per cent, 60 per cent and 50 per cent respectively over open field cultivation.
\end{abstract}

\section{Introduction}

India is second largest vegetable producer in the world next to China; however it's per capita per day availability is well below $92 \mathrm{~g}$ whereas the recommended consumption is 284 g. Protected cultivation technologies are being utilized all over the world but the level and extent of their use may be different among different countries. Agronomical practices play an important role for obtaining higher yields especially under protected structures. To make its cultivation successful, polyhouses and plastic-mulching are most suitable solutions (Chandra et al., 2000; Singh et al., 2004 and 2010). The production of off-season vegetable crops under net house conditions was evaluated for total yield, earliness and other character and incidence of insect pests (Cheema et al., 2004). The cultivation of vegetables in net house can play a better role in improving quality, advancing maturity as well as increasing fruiting span and productivity. Singh and Sirohi (2008) reported that protected cultivation of vegetables offers distinct advantages of quality, productivity and favourable market price to the growers.

Dixit (2007) studied the performance of leafy vegetables under protected environment and open field condition. Protected structure offers an opportunity for extended period of cultivation under frost free and comparatively higher night temperature conditions. Singh and Asrey (2005) also recommended that cultivation of tomato in a greenhouse would help obtain high productivity and better return. Tomato (Solanum lycopersicon L.) is available throughout the year in India. Therefore, an effort has been made to study the performance 
of tomato crop under shade net house as well as open field condition.

\section{Materials and Methods}

The field study was taken up to evaluate the performance of tomato crop (Solanum lycopersicon L.) in open field and under shade net house with $50 \%$ shade factor. The study was laid out during October 2017 to March 2018 under shade net house. The stusy was conducted in farmers field in Majgawa village, district Shahdol (MP). The tomato crop selected for study was 30 day after transplanted in shadenet and open field condition with a spacing of $60 \mathrm{~cm}$ plant to plant (P-P) and $30 \mathrm{~cm}$ row to row (R-R).

\section{Results and Discussion}

The result are presented under the heads i) Plant characteristics ii) Yield parameter.

\section{Plant growth characteristics}

Plant growth characteristics such as plant height, number of branches, total number of harvesting, harvesting duration were measured for tomato crop under shade net house and open field was shown in Table 1.

The plant height, number of branches per plant, number of harvesting and harvest duration were higher for the tomato crop cultivation in shade net over open field. Total harvest duration in shade net house was 72 day and 45 in open field.

\section{Yield parameter}

Yield parameter such as fruit weight, ten fruit weight, number of fruit per plant, yield per plant and yield per ha. was measured and shown in Table 2. In shade net house fruit size was big and fruit weight was $62.45 \mathrm{~g}$ and in open field fruit quality was small and fruit weight was $35.42 \mathrm{~g}$. Total numbers of fruit per plant was recorded higher (95) in shade net as compare to open field (59) with an impact shown on yield i.e. per plant yield was more in shade net house tomato cultivation is $8.2 \mathrm{~kg}$ and open field condition is $5.2 \mathrm{~kg}$. Tomato yield was $385 \mathrm{q} / \mathrm{ha}$ in open field and $675 \mathrm{q} / \mathrm{ha}$ in shade net house.

Table.1 Performance of tomato crop

\section{Plant height, cm Number of branches Number of harvesting Harvest duration, days}

\begin{tabular}{|l|l|l|l|l|}
\hline Open field & 78.20 & 32 & 4 & 45 \\
\hline Shade net & 109.5 & 43 & 6 & 72 \\
\hline
\end{tabular}

Table.2 Performance of tomato yield parameters

Fruit weight, g Ten fruit weight, g Number of fruit per plant Yield per plant, kg Yield per ha, $q$

\begin{tabular}{|l|l|l|l|l|l|}
\hline Open field & 35.42 & 455.3 & 59 & 5.2 & 385 \\
\hline Shade net & 62.45 & 620.7 & 95 & 8.2 & 675 \\
\hline
\end{tabular}

Table.3 Percentage improvement in tomato performance

\begin{tabular}{|c|c|c|c|c|c|}
\hline Yield per ha & $\begin{array}{c}\text { Number of fruit per } \\
\text { plant }\end{array}$ & Fruit weight & $\begin{array}{c}\text { Plant } \\
\text { height }\end{array}$ & $\begin{array}{c}\text { Harvest } \\
\text { duration }\end{array}$ & \begin{tabular}{c} 
Number of harvest \\
\hline $\mathbf{7 5 . 3 2}$
\end{tabular} \\
\hline 61 & 76.3 & 40.03 & 60.00 & 50.00 \\
\hline
\end{tabular}




\section{Performance improvement}

Table 3 reveals that yield per ha, number of fruit per plant, fruit weight, plant height, harvest duration and number of harvest were $75.32,61,76.3,40.03,60,50 \%$ more respectively, under shade net house condition compared to the open field condition. These findings demonstrate the suitability as well as economic feasibility of shade net house as compare to open field condition in adverse and off season condition in Shahdol district. Therefore, it may be concluded that shade net house could be a feasible option growing farmers for tomato to obtained higher yield as compare to open field condition. It the present study experimental trials were taken up to study the performance of tomato crop under shade net having 50\% shade factor in comparison to open field cultivation. The findings of the study revealed that under shade net the crop yield was increase by 75.32 per cent over open field cultivation.

\section{References}

Chandra, P., Sirohi, P.S., Behera, T.K. and Singh, A. K. (2000). Cultivating vegetable in polyhouse. Indian Hort., 45 (3): 17-32.

Cheema, D.S., Kaur, P. and Kaur, S. (2004). Off-season cultivation of tomato under net house conditions. Acta Hortic. 659, 177-181 DOI: 10.17660/ActaHortic.2004.659.21

Dixit, A. (2007). Performance of leafy vegetables under protected environment and open field condition. Asian J. Hort., 2 (1): 197- 200.

Singh, B. and Sirohi, N.P.S. (2008). Protected cultivation of vegetables in India: problems and future prospects. Acta Hort., 710: 339-342.

Singh, B., Kumar, M. and Sirohi, N. P. S. (2004). Cultivation offseason summer squash. Indian Hort., 49 (1): 9-11.

Singh, B., Singh, A. K. and Tomar, B. (2010). In peri-urban areas protected cultivation technology to bring prosperity. Indian J. Hort., 55 (4): 31-33.

Singh, R. and Asrey, R. (2005). Performance of tomato and sweet pepper under unheated green house. Haryana J. Hort. Sci., 34 (1-2): 174-175.

\section{How to cite this article:}

Deepak Chouhan, Mrigendra Singh, P.N. Tripathi and Alpana Sharma. 2018. Effect of Green Shade Net on Yield and Quality of Tomato. Int.J.Curr.Microbiol.App.Sci. 7(09): 2148-2150. doi: https://doi.org/10.20546/ijcmas.2018.709.263 